\title{
Integration of Religion and Culture as a Basic to Beyond the Meaning (Study on Reyog Ponorogo)
}

\author{
Rido Kurnianto $^{1 *}$, Nurul Iman ${ }^{1}$, Sigit Dwi Laksana ${ }^{1}$ \\ ${ }^{1}$ Universitas Muhammadiyah Ponorogo, Ponorogo, Indonesia \\ "Corresponding author. Email: kurnianto.mama@gmail.com
}

\begin{abstract}
This article examines the integration between Islam and culture in Reyog Ponorogo Art. The noble values contained in Reyog Ponorogo art, which has been latent, it is very possible to be studied more deeply through the symbols contained in the equipment and the variety of the dance, to be actualized in the form of explicit meanings as the basis for the transformation of meaning in the community. In certain contexts, the meaning and truth of teaching often do not appear explicitly, so that it requires cultural action to uncover it, one of which is through cultural symbols. In Berger's theory, it is explained that a symbol always has cultural significance and resonance. It has the ability to influence and also has a deep meaning. This type of research is qualitative. Data collection techniques in this study used in-depth interview techniques, participant observation, and documentaries. The analytical technique used is descriptive-analytical. The data that has been collected is analyzed using qualitative methods. The analysis was carried out while in the field and afterfield analysis using analytic induction techniques. Through this study, it was found that the character values contained in Reyog Ponorogo art, including the historical component, equipment, fashion, and dance variety have very strong relevance to the values of Islamic education and are very strategically integrated for the purpose of inculcating values Islamic education at Konco Reyog Ponorogo.
\end{abstract}

Keywords: Reyog Ponorogo, Islam science, culture

\section{INTRODUCTION}

As a caliph on earth, humans are the most beautiful creatures who are endowed with the basic abilities of imagination, with which they are able to develop aesthetic abilities in the form of (concrete forms) are art and culture, both immanent and transcendent. Art and culture are manifestations of the feeling of beauty that is brought from birth by every human being as a gift from God, which is a nature that must be maintained and channeled in life.

Aesthetic experience is a means of searching for meaning and uncovering the truth hidden behind certain symbols. The meaning and truth of teaching often do not appear explicitly (mantuq), so that with cultural activities, it will be easily revealed. Perhaps this is what is meant by Berger, that a symbol, always has a cultural significance and resonance. The symbol has the ability to influence and also has a deep meaning [1]. Through this symbol, the meaning of life is grown, as Mudji Sutrisno wrote, that through culture the meaning of life is lived and through the symbol of the meaning of life is discourse and lived [2].

Art and culture are necessities of life and in many ways contain benefits, both in terms of content and function. In terms of content, art and culture convey piwulang, advice, criticism, stories about truth and goodness. In terms of its social function, it can create peace (peacemaker), a means of reconciliation, break the ice, freeze tension, and so on. In the perspective of da'wah, art and culture are the means of forming human beings into our human beings (perfect humans). More clearly, we can be defined as God's servants who are able to carry out the truth in the right way and convey the truth in an ethical and cultured way (through the charm of tenderness, polite speech, and the subtlety of character).

During this time, the reality of the existence of art and culture in the midst of human life often happens "bias" attitude. There are those who totally utilize art and culture as a strategy to face life, although not infrequently their use is still often trapped in the aspect of "watching" or "entertainment" (play) and has not touched on the level of meaning or "guidance" (display), which leads people goodness and progress. Some of them react "half-hearted". Some of them even refused to the extreme - forbidding it. Facts as explained above also occur in Reyog Ponorogo art. Reyog's art with its tiger head and peacock's pillar instruments, one side has been recognized by the government and the people of Ponorogo Regency as a noble art (dignified), mainly because of the beauty of the artistic material along with the content of the noble meaning it contains. While on the other hand, this art continues to be "suspected" as the culprit of the birth of a number of negative behaviors, such as drinking, showing off immunity, mystical action, eroticism, and others. Even a number of these behaviors seem "common" and become "stigmatized" until now. The negative stigma is very difficult to stem because it is inherited systematically and hereditary. Over time, the presence of a number of Islamic boarding schools and schools that included Reyog Ponorogo as a basis for character development, the noble values contained in Ponogogo Reyog art began to be penetrated [3]. 
This article will try to analyze the art and culture in relation to the possibility of using it to build a beautiful and polite society through the pillars of beauty that are revealed in the art of Reyog Ponorogo and then analyzed its meeting point integrally with the values of beauty that are woven into the teachings, Islam). The fabric of integration in Reyog Ponorogo art and the values of religious teachings is then examined to see its relevance to the cultivation of virtue values in the community.

\section{METHODS}

This study uses a qualitative case study model approach to the integration of religion and culture that occurs in Reyog Ponorogo. Data collection techniques use a combination of observation, documentation, and in-depth interviews. Data analysis uses descriptive analytical techniques. The data obtained in the field are processed in such a way before entering the analysis phase. At the processing stage, the data undergoes a process of editing and systematization. Editing is intended to complement, explain and find the relevance of data with a research focus. Systematization is carried out as a follow-up to the editing process so that the data is arranged systematically in terms of data exposure [4].

\section{RESULTS AND DISCUSSION}

\subsection{The Paradigm of Human Awareness}

Human awareness, according to cultural experts, is a determinant of changes in community values, in addition to material bases; economic, political and social. Human consciousness is the key to cultural transformation. When the pivot of the material structure and the economic, political, and social basis are the foundation of transformation, then the structural change of material will determine civilization.

Art is a sacred expression of fitriah. Art brings joy in the soul, excitement thrills human emotions. Intense emotions move attitudes and behavior. Attitudes and behaviors shape personality [5]. From him, good morals are born. Therefore, between the arts and morals as if they are in a room that is not insulated. Both are in line with siring in harmony.

In art, teachers and students are often involved in a very intense emotional atmosphere. Intense emotions are not something that is forced but are created naturally along with with with the artistic activities that are passed [5]. Art is often believed to be a gift that was handed down. This view is based on the notion of art itself. Art comes from 'sani' (Sanskrit) which means worship, offerings, or services. This understanding was born in the initial context more widely used in religious ritual activities. In Dutch, art comes from the word genie (in Latin called "genius") meaning extraordinary abilities that are carried from birth. Based on this understanding, Ki Hadjar Dewantara in Purwanto [6], understanding the meaning of art as a result of beauty that can move the beautiful feelings of people who see it.

\subsection{Religious and Cultural Tensions}

Culture is not mentioned by law in the Koran or Assunnah. In the rules of ushul fiqh explained that for something that is not explicitly explained in the Qur'an and Assunnah, then something becomes permissible (may) be done until there is a clear argument forbidding it. "Al ashlu fi al-asyya 'alibahah" (the original law of all things is permissible).

The occurrence of cultural and religious tensions is caused more by the attitude of its adherents - a crisis of appreciation. A less appreciative attitude towards art and culture and its community (creator, actor, lover) is often triggered by the understanding of religion which is based on religious authority which emphasizes Shari'ah laws that are taklifi (black-and-white) and not wad'i. Besides that, it is also caused by a bureaucratic system that homogenizes and equalizes the life of a community, so that it has unknowingly changed a culture that should be dynamic to be static and tedious. Yet since the Prophet Muhammad, intercultural encounters and dialogues (multicultural) and between religions (multireligious), have even occurred very beautifully. The Medina Charter is an authentic document, as well as evidence that encounters between cultures and between religious communities, have taken place very beautifully.

Seeing the relevance of culture and religion as well as considering the effectiveness of the power to change the positive direction brought by cultural arts, many community organizations and religious organizations make culture as a means to convey teachings (religion). In fact, Muhammadiyah, which is accused by many as being "anticultural", has actually proclaimed cultural propaganda through the 2000 Tanwir Session in Bali, by stating firmly, that art and culture are not only immortal, even ma'ruf and are the mercy of God. This attitude is a reinforcement of the previous attitude, namely the National Conference XXII in Aceh in 1995, which at that time decided the following results: (1) art is human nature; (2) the law of art is permissible as long as it does not cause damage, danger, lawlessness, and distance from God; (3) art that is intended to enhance the quality of faith is worship. Furthermore, in 2000 through the National Conference of XXIV in Jakarta, this attitude was further strengthened until the birth of cultural propaganda which continues to be ignited until today.

While among the Nahdatul Ulama, the issue of cultural traditions that developed in the community has been used as a means of da'wah, since the beginning of its development. Even the integration of religious and cultural teachings has taken place and was built from the beginning through acculturation and inculturation. From it has given birth to a variety of cultural traditions in which integrated Islamic values, without eliminating the physical container of local cultural traditions.

\subsection{Strategy for Integration of Religion and Culture}

Abdullah interprets integration by linking the term interconnection, which is the process of complementation 
in the context of interrelation with one another, exchanging greetings, filling each other with weaknesses and strengths [7]. In the Journal of Sufism and Islamic Thought Volume 3 Number 2 December 2013 written by Siswanto entitled Perspective Amin Abdullah explained, that integration and interconnection between disciplines, both from secular scholarship and religious scholarship, will make them interrelated with each other, "admonish greet", complement each other's strengths and weaknesses. Thus, the science of religion (Islamic science) no longer dwells on the text will unite the three, but at the very least, there will be no more superiority and inferiority in science, there are no more claims of the truth of science so that with this paradigm the scientists who pursue this scholarship will also have attitudes and ways of thinking that are different from before. The civilization of science, namely empirical sciences such as science, technology, and the sciences related to reality no longer stand-alone but also come into contact with the civilization of philosophy so that they continue to pay attention to emancipatory ethics. Vice versa, philosophical civilization will feel dry and arid if it is not related to religious issues contained in the culture of the text and even more so if it is far away from the problems posed and faced by the civilization of science. This civilization gave birth to a single entity pattern, isolated entities, and interconnected. Based on the above rationale, it can be concluded that culture and education cannot be separated, they both support and strengthen each other. As said by Ki Hajar Dewantara [8] that culture is the basis of educational philosophy, while education is the main guardian of culture. Because the role of education is to shape people to be cultured, it is like education without culture like a boat in the ocean without direction.

In the world of education, experts have recognized the effectiveness of art and culture in instilling various intelligences, namely intelligence intelligence, emotional intelligence, and spiritual intelligence, as written by Roqib, that through the process of education through culture, various intelligence (intellectual, emotional, spiritual intelligence, individual intelligence/adversity quotation) is more effectively implanted and is more likely to form themselves with a positive level of flexibility when facing life's obstacles. In other words, it is more possible to survive and overcome them [9]

Meanwhile, Islamic education by using culture as a medium of value transformation is very necessary, and as part of the formation of Muslim identity through the environment with its religious educative symbols,[9] even in Islam it is necessary to enrich cultural symbols, because it will be more easily accepted than religion itself, including in this post-modern era.

Qur'an itself in conveying its messages (in the form of guidance and instructions), also uses a variety of uslub (style), one of which is through proverbs (parables), the purpose of which is nothing but that the instructions and guidance can be easily accepted as a lesson. "And indeed we have made it easy for the Koran to become a lesson, then is there anyone who takes lessons" [10]. Through proverbs (parables), the Qur'an expresses abstract concepts with concrete meanings, in which the interaction of the human senses is given a prominent role. This method has a direct application in education and teaching so that whatever is in the environment associated with mass (parables) helps accelerate the process of understanding, while also fostering human reason to get accustomed to think correctly and make sense [11].

The effectiveness of culture as a medium of communication is also recognized by cultural experts. In fact, according to Kuntowijoyo, they can interact reciprocally to share influence. He wrote, that the interaction between religion and culture can occur through various forms; (1) religion influences the formation of a culture/culture, so that religion manifests into a value, while culture embodies its symbol; (2) culture can influence the formation of religious symbols; and (3) culture can replace the system of values and religious symbols [12].

Symbols are usually classified into two, namely the dominant symbol and the instrumental symbol [13]. The term dominant symbol was written by Turner [14], where Ortner called it the key symbol [15]. Dominant symbols or key symbols appear in various ceremonial contexts, but sometimes also include special phases. Whereas instrumental symbols emerge in a broader context, namely the whole symbol system that describes the shape of a ceremony. This study will focus on the dominant symbol because it is considered not only to have success and expectations recognized through a ceremony but also refers to values that are seen as goals in themselves, namely to values that cannot be refuted [14].

The dominant symbol has three characteristics that need attention: (1) the dominant symbol is the condensation which is the simplest trait; (2) the dominant symbol is the union of different meanings, which are often connected or united by common traits that are in line or through association in reality or ideas; (3) the dominant symbol has the opposite meaning [16].

Symbols will affect the life of a society, as Geertz points out, that the concept of human existence and place in the universe and its contents and various matters relating to life cycles are related to the balance or imbalance in life [17]. Some steps that can be recommended to knit the harmony of Religion and Culture are as follows: (1) Islamization of Objects. This method is carried out to modify or create the local culture to fit religious boundaries (Islam), both in terms of content and expression; (2) Islamization of the Subject. This method is carried out to integrate religious values (Islam) into the minds and souls of cultural practitioners; (3) Rationalization. This method is used to utilize local culture as a means to arrive at goodness and truth; (4) Organization. This method is used to eliminate the "sacred" impression of a particular art and present it profanely as mere entertainment; (5) Spiritualization and Mutual Understanding. This method is carried out to give religious and spiritual colors to the content (content) and cultural expression, so that it can be used to refine religious language (da'wah) and maintain social tensions, social integration, and dilute social tensions; and (6) Pluralization. This method is used to refine the "extreme" category that often gives birth to conflict.

In the integration process, it is possible to have a variety of perspectives and even sharp differences. Managing differences and at the same time becomes an important issue that must be done. An important principle in managing this is, "differences are not a scourge to be feared", equality and 
uniformity are not goals ". The basic issue that must be understood in this context is the willingness to "greet one another" and "understand each other" between components of society. So far, it seems that the cultural and religious communities are comfortable in their respective ivory towers. Local wisdom contained in the cultural treasures seems not to be able to meet with the universal wisdom contained in religious teachings. Whereas from the beginning, Rasulullah Saw has given a concrete example of the integration of religion and culture, especially when he built a civilization in Medina. The Muslim community under his leadership beautifully mingled with non-Muslim societies (even infidels) and at the same time greeted their culture until religious values intermingled and characterized the life-things of the nation-state which were plural in terms of ethnicity and culture and had been documented very beautifully in the "Charter of Medina".

\subsection{Integration of Character Values in Reyog Ponorogo}

Reyog Ponorogo art is not just an artistic or aesthetic value, but it contains noble values that can be used to instill the attitude of the main personality and superior life attitude for the wider community. The aesthetic value of Reyog Ponorogo art is explained in sufficient detail by Nursilah that in Reyog Ponorogo performing arts there is an aesthetic value [18]. The uniqueness of Reyog Ponorogo art, thus, lies not only in the display of the instrument and its cultural symbols, but also in the noble values it contains, both those that are revealed in history, instruments or equipment, as well as in the variety of dance. These noble values include; courage to convey the truth as derived from the history of the Surukubeng version, fair leadership as derived from the history of the Bantarangin version and the Batharakatong version, noble character as symbolized by the peacock, courage to defend the truth as symbolized through the tiger animal, patriotism/heroism as symbolized through jathil dance, optimism as symbolized through the pujangganong dance, leadership as symbolized through the Kelanasewandono dance, and so on.

The art symbols used in the Reyog Ponorogo art which have noble values have not been explored until now. This is due to the fact that Reyog Ponorogo's art is more focused on the development of its performance art, and only pays little attention to the aspect of the symbol's meaning. Indeed, there has been a movement towards extracting the meaning of Reyog's art symbols, especially in Student Reyog art, but its nature is still very simple, not even a structured movement. The integration of character values in the Reyog Ponorogo art, thus, is very strategic to be integrated with religious values through learning Reyog art in schools.

In detail, the values in Reyog Ponorogo art are explained in four components, namely; Reyog's history, art equipment or instruments, clothing/costumes, and dance variety. Reyog's history, including; Bantarangin version, Surukubeng version, and Batharakatong version. Equipment components include; drums, ketipung, kenong, kethuk, angklung, trumpet, kempul, peacock, tiger, and samandiman whip. Clothing/costume components, including; drawstring/intestines, penadon clothing, udheng. While the components of the dance variety include; warok dance, jatil dance, ganongan dance, kelanasewandana dance, and peacock dance.

The character values contained in the historical components of the Bantarangin version, the Surukubeng version, and the Batharakatong version are brave, optimistic, and fair. The character of courage is illustrated by the action of Ki Ageng Kutu in the form of his courage to criticize King Brawijaya $\mathrm{V}$ related to his insistence on making and implementing government policies due to the dominance of his empress (Raja's wife). The value of optimism is very prominent and is very clear in the attitude of Kelanasewandana and $\mathrm{Ki}$ Ageng Kutu in the action towards the stated goal. Kelanasewandana appears in her persistence in realizing the conditions proposed by the woman who will be invited to her (Putri Sanggalangit). The three requirements requested are all "impossible" to realize, because it is not only complicated but also impossible for a human being to do. While Ki Ageng Kutu's optimism appeared in his actions in taking the worst risks, namely being fired from the royal "retainer" to the risk of being imprisoned and even killed by the King. Fair character is seen in the leadership attitude of Kelanasewandana which always puts honesty and fairness forward. Likewise, this character also looks very strong in Batharakatong's leadership. Character values in the historical component can be integrated into the teachings of Islam, namely syaja'ah (courage in defending the truth), always hoping for God's grace, and 'is (always behaving and acting fairly in life) as opposed to dhalim (cheating, discriminatory, likes to hurt people or other parties, put something out of place, and so on).

Character values contained in the Reyog Ponorogo equipment component/instrument, including; drums, ketipung, kenong, kethuk, angklung, trumpet, kempul, peacock, tiger, and samandiman whip. The character value of kendang is controlling as this gamelan instrument controls the whole rhythm in Reyog Ponorogo art. This character value can be integrated into self-control as the value of religious teachings, which is to control oneself from everything that is forbidden by God. In Arabic kendang bida is synonymous with qada'a which means selfcontrol. This character value is strengthened by the ketipung tool which in Reyog's rhythm is used as an interrupted tone (in reply to Reyog's rhythm). The character value of this tool integrates with retribution in religious teachings, that everything done by humans will get a reward from God. Therefore, humans must be careful in living their lives, so that their steps in the world are filled with virtue and glory. The character values in kenong and kethuk instruments as a pair of Reyog gamelan instruments which are always sounded in tandem mean the importance of balance in facing life. Kenong means active "surrender", which means accepting gifts from God after making maximum efforts. In Islamic teachings, this attitude is called qana'ah which is a noble character related to the attitude that should be possessed by Muslims in accepting the gift of their Lord. While kethuk means mathuk (suitable, appropriate), it means adjusting the attitude of resignation to the provisions of God after making the maximum effort will always reduce the introspective attitude towards mistakes that are very likely to be made in the endeavor. In the teachings of 
religion this tool is interpreted as khatha '(wrong), meaning that humans are the wrong place, so it is very important to always be introspective with mistakes made, whether intentional or not, large or small. This character of resignation and introspection is very strategic to be integrated into instilling the values of Islamic education, namely qana'ah (the attitude of accepting God's gifts in a field after maximum efforts) and I'tiraf (always acknowledging mistakes and accompanying them with requests for forgiveness or repentance to Allah SWT).

The character value in the angklung instrument with the sound of $k r i k \ldots k r o k \ldots k r i k \ldots k r o k$ is a contrasting interlude with the function of beautifying the gamelan rhythm. Contrast is also interpreted to mean that in order for life to be noble it must be able to sort out what is good and what is bad. In Islamic teachings, the term sort is called hijrah (intiqal), which is to leave something that is ugly or unfavorable towards something good and noble. These character values can be integrated into the teachings of hijrah, which is moving from a dark life to a bright life.

The character value in the trumpet instrument is a warning of death, which the sound of a warning about the journey of human life to death always sounds. Therefore, humans must always be armed with the best stock to pick up death. In Islamic teachings, the warning signs of death are various signs. This character value can be integrated through the depiction of shuwar that is manifested through various signs leading to death.

The character value contained in the kempul equipment is seen from the sound character of this tool, which is woof ... woof ... woof and functions as a closing gending. From the sounding character, kempul is also called gong. In closing the gending, kempul means the final stop, a kind of responsibility. This tool is interpreted as a picture of the peak or end of a long journey to God. Every ascent of life will surely end in God's rule. The value of Islamic education that can be integrated with the character value of this tool is responsibility and love for God.

The character value contained in the peacock is beautiful, beautiful as shown in the beauty and beauty of the peacock. In the values of Islamic education beautiful and beautiful relating to the morals or ethics that must be owned by everyone. The character value can be integrated into the noble or noble personal cultivation. While the caploan instrument which comes from a replica of a tiger and is a pair of peacock equipment has the value of physical and mental strength. These character values can be integrated into the values of a strong and beautiful Islamic education. In Islam, strong believers are better than weak believers.

The value of character contained in the Samandiman whip is magic. As a perfect weapon of Kelanasewandana, the power of the whip of samandiman is described as being able to devastate mountains and make the ocean dry when hit by these weapons. This character value can be integrated into the values of Islamic teachings, especially related to the concept of Islamic leadership. A strong leader is a leader who bases all his leadership policies and actions on the Holy Qur'an and the Sunnah of the Prophet. Leaders like this who deserve to be obeyed (sami'na wa atha'na).

During the reign of Batharakatong, the Reyog instrument/equipment was used as a tetenger (warning, lesson) so that humans would not forget themselves as their creatures must serve God and do well to others. Therefore, as explained in the Yellow Book, the Reyog equipment was set to number 17 units, with details: Barongan (2 pieces); Pujangganong masks (1 piece); Mask Patrajaya and Patrathala (2 pieces); Eblek (jaranan (2 pieces); Kendang (1 piece); Ketipung (1 piece); Trumpet (1 piece); Kempul (1 piece); Kethuk and Kenong (2 pieces); and Angklung (4 pieces)[19] The number 17 is intended as a warning about the obligation of humans to worship their Lord in the form of prayer or prayer 5 (five) times as much as 17 rak'ahs in a day and night, namely: Fajr (2 raka'at); Dhuhur (4 raka 'at); Asr (4 raka'at), Maghrib (3 raka'at); and Isha' (4 raka'at).

The various meanings of these symbols have a common ground with the values of Islamic education. Based on the findings of research conducted by Rido Kurnianto and Niken Lestarini on Konco Reyog Ponorogo character education based on Islamic education, that in Reyog Ponorogo art contained Islamic educational values, including; the creed, worship, and morals which are revealed in the meaning of the symbol, both those contained in the instrument and the variety of dance instruments (Kurnianto and [20].

The pillar of religious education (faith) is revealed in two aspects, namely the opening of the stage and the symbol of the weapon "Pecut Samandiman" (weapons belonging to the king Kelanasewandana in the form of a kind of whip). The opening of Reyog's art stage became a religious education because when Reyco Reyog started the stage, they started it by saying prayers to Allah, through various creations (attitudes, song or song poetry, dance, etc.). In the research conducted by Kurnianto in 12 (twelve) schools in the Ponorogo Regency, each group started the stage where and in any form by praying together.[20]

While the pillars of religious education which are revealed in the meaning of the Samandiman Pecut symbol, are read in the composition of the Pecut, which are five bundles and one pillar. Five ties are intended as the five pillars of Islam (Creed, Prayer, Fasting, Zakat, and Hajj). While one pillar in the form of a whip is a symbol of monotheism (oneness of God).[20] Therefore, in the stage, when this weapon was used against Singo Barong (peacock) which was said to be strong was invincible, then he immediately collapsed helplessly, even the universe around him was affected by a very terrible impact. This is intended as a description that, when someone has firmly believed in God accompanied by the practice of the pillars of Islam, then there will not be any strength in the universe that can weaken it, because he has been strongly linked to the power of God Almighty.

Character values contained in the clothing/costume component, including; drawstring/intestines, penadon clothing, udheng. The character values found in the costume of the intestines or drawstring are strong binders, meaning that life must be bound with a strong bond so that life is not easily swayed every time a storm is tested for life. This character value can be integrated with the value of Islamic education in life guidelines, namely the life guidance that has been outlined by God through the Qur'an and the Messenger of Allah through the Sunnah. In Arabic, this word is called asas or ususun (plural), which means a strong foundation or foundation. 
The character value found in the penadon costume is simplicity in evaluating oneself. The black color that underlies the penadon shirt is a symbol of "establishment", which is a condition of the self that has been fixed (closed from all lust desires). The red alloy in this costume means glory. The person who has been saved just wants perfection towards eternity. This character value is relevant to be integrated with the value of Islamic education, namely muhasabah (introspective) by always being forgiving (sensitive to mistakes or lack of self) then purifying himself with a request for forgiveness to God Almighty and accompanying it with virtues.

The character value contained in the udheng costume is read from the position of this costume which is always above the head which means glory. The above position means always caring about sharing virtue in various contexts. The above position means also as a director and advisor (noble pitutur). In Arabic, this costume is synonymous with $u d^{\prime} u$ (say, invite) your fellow towards goodness. In this sense the character value in this costume can be integrated through various life activities.

While the components of the dance variety include; warok dance, jatil dance, ganongan dance, kelanasewandana dance, and peacock dance. The value of character in warok dance is the attitude of caution by maintaining the purity of the self and spirit. Humility and affection are also character values in this dance. The peak kanoragan (the science of strength and immunity) makes a warok gentler and wiser. All the power of self is devoted to the benefit of others. In Islam, this character is called wira' $i$ (a peak personality in a humanitarian context). In this context the character values contained in the Warok dance can be integrated.

The character value contained in Jatil dance is patriotism. This dance was originally played by male dancers because its philosophical value is the depiction of the attitude of a horseman who is skilled at fighting against the enemies of the State. Besides describing war skills, this dance also illustrates the high awareness of all things that will threaten the security and peace of the country and nation. Therefore, even in its development, the cast of jatil dance turned into a woman, precisely since 1988 (during the reign of the Subarkah Regent) in the context of fulfilling the request of the Government of the Republic of Indonesia (in the era of President Suharto), namely the Jakarta Fair Festival so that jatil dancers are played by dancer women, but movements must remain firm, agile and agile. The character values in jatil dance, namely patriotism, can be integrated into the values of Islamic education, namely the attitude of vigilance towards enemy attacks that can come at any time.

Character values in the ganongan dance include; the inevitability of the life test and at the same time being prepared to deal with it with space and tenacity. Therefore, this dance combines acrobatic, attractive skills which often invites tension, and is also interspersed with humorous dance that always invites audience laughter. The character values contained in this dance can be integrated into the values of Islamic education, namely; patient and optimistic. The character values contained in the kelanasewandana dance are derived from the personal character and the leadership model they demonstrate. Kelanasewandana is a leader figure (King) who is so wise that he is ordained like a god. His wisdom in leading the country and his people led him to be very loved by his people. While his firm and brave personality make him dare to face any risk, to meet the heavy requirements when applying for Dewi Sanggalangit (Putri Raja Kediri). Requirements in the form of 3 (three) types include; 144 bridesmaids' horsemen, offering unique entertainment that no one has in the world and an underground passageway as a bridal party from Ponorogo to the kingdom of Kediri. Character values in this dance include; wisdom, courage, and honesty that can be integrated into the values of Islamic education, namely; Wira'i, Syaja'ah, and honest.

While the character value contained in the peacock or barongan dance is beauty derived from the beauty and beauty of peacocks, courage, and authority derived from tiger or tiger characters. These character values can be integrated into the values of Islamic education, namely; morality of mercy, syaja'ah, and entrepreneur.

\section{CONCLUSION}

In a changing era, one side of Reyog Ponorogo art must maintain its character as a folk art with a number of pillars rooted in the traditions of the people. While on the other hand must go out of the traditional "zone" to adjust to the conditions that surround. In this context, the basic character values must continue to be guided in the adjustment of space and time, so that any changes or adjustments related to Reyog Ponorogo art trinkets will never shift the basic characters full of noble values. The character values revealed in the Reyog Ponorogo art component have strong relevance to the values of Islamic education and are very strategically utilized to strengthen character learning based on local wisdom. The inculcation of Reyog Ponorogo artbased Islamic education values is very effective considering that internally it has been supported by the attractiveness aspects of Reyog Ponorogo art

\section{REFERENCES}

[1] A. A. Berger, Tanda-Tanda dalam Kebudayaan Kontemporer; Suatu Pengantar Semiotika. Yogyakarta: Tiara Wacana Yogya, 2005.

[2] M. \& H. P. Sutrisno, Teori-Teori Kebudayaan. Yogyakarta: Kanisius, 2008.

[3] R. Kurnianto, Seni Reyog Ponorogo; Sejarah, Nilai, dan Dinamika Dari Waktu ke Waktu. Yogyakarta: Buku Litera, 2017.

[4] M. M. B. and M. Huberman, Qualitative Data Analysis A Sowerebook of New Metodhs. New York: Sage Publications., 1987.

[5] S. Purwanto, Pendidikan Karakter Melalui Seni. Yogyakarta: Pustaka Pelajar, 2016.

[6] S. Purwanto, Pendidikan Karakter Melalui Seni. Yogyakarta: Pustaka Pelajar, 2016. 
[14] V. W. Turner, Symbol in Ndembu Ritual. Ithaca: Cornell University Press, 1967.

[15] S. B. Ortner, On Key Symbols. Asen: Van Gorcum, 1967.

[16] I. Abdullah, Simbol, Makna, dan Pandangan Hidup Jawa; AnalisisGunungan pada Upacara Garebeg. Yogyakarta: Balai Kajian Sejarah dan Nilai Tradisional, 2002.

[17] C. Geertz, Abangan, Santri, Priyayi dalam Masyarakat jawa. Jakarta: Pustaka Jaya, 1983.

[18] Nursilah, Reyog Ponorogo Kajian Terhadap Seni Pertunjukan Rakyat Sebagai Pembentuk Identitas Budaya. Jakarta: FISIP UI, 2001.

[19] Pemerintah Kabupaten Ponorogo, Pedeoman Dasar Kesenian Reyog Ponorogo dalam Pentas Budaya Bangsa. Ponorogo: Pemkab Ponorogo, 2013.

[20] R. dan N. L. Kurnianto, Pendidikan Karakter Konco Reyog Ponorogo Berbasis Pendidikan Islam. Ponorogo: LPPM UNMUH Ponorogo, 2016.
[13] Kuntowijoyo, Muslim Tanpa Masjid, ; Esai-Esai Agama, Budaya, dan Politik dalam Bingkai Strukturalisme Transendental. Jakarta: Mizan, 2001. 